\title{
WORKING LIVES
}

\section{Essays in Canadian Working-Class History}

Craig Heron is one of Canada's leading labour historians. His latest work draws together fifteen of his new and previously published essays on working-class life in Canada and covers a wide range of issues, including politics, culture, gender, wage-earning, and union organization. A timely contribution to the evolving field of labour in Canada, this cohesive collection analyses the daily experiences of people working across Canada over more than two hundred years.

Honest in its depictions of the historical complexities of daily life, Working Lives raises issues in the writing of Canadian working-class history, especially "working-class realism," and how it is eventually inscribed into Canada's public history. Thoughtfully reflecting on the ways in which workers interact with the past, Heron discusses the important role that historians and museums play in remembering the adversity and milestones experienced by Canada's working class.

CRAIG HERON is a professor emeritus in the Department of History at York University and author of Working Steel: The Early Years in Canada, 1883-1935, also published by University of Toronto Press. 
This page intentionally left blank 


\title{
Working Lives
}

Essays in

Canadian Working-Class History

\author{
CRAIG HERON
}

UNIVERSITY OF TORONTO PRESS

Toronto Buffalo London 
(C) University of Toronto Press 2018

Toronto Buffalo London

utorontopress.com

Printed in Canada

ISBN 978-1-4875-0325-3 (cloth)

ISBN 978-1-4875-2251-3 (paper)

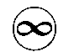

Printed on acid-free, $100 \%$ post-consumer recycled paper with vegetable-based inks.

\section{Library and Archives Canada Cataloguing in Publication}

Heron, Craig, author

Working lives : essays in Canadian working-class history / Craig Heron.

Includes bibliographical references.

ISBN 978-1-4875-0325-3 (hardcover) ISBN 978-1-4875-2251-3 (softcover)

1. Working class - Canada - History. 2. Social history - Canada. I. Title.

HD8104.H47 2018

$305.5^{\prime} 620971$

C2018-903306-1

University of Toronto Press acknowledges the financial assistance to its publishing program of the Canada Council for the Arts and the Ontario Arts Council, an agency of the Government of Ontario.

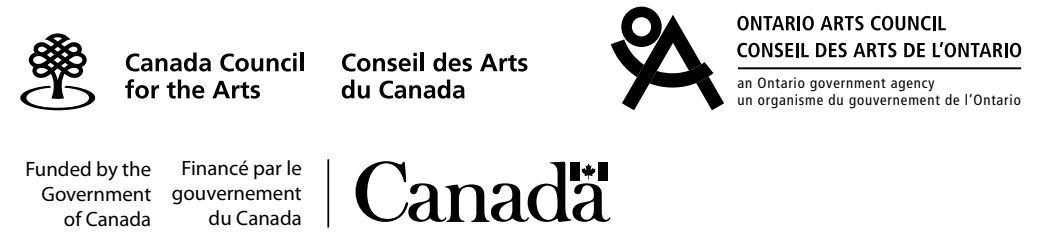

